\title{
An Unusual Dicarboxylic Acid from the Giant Jellyfish Nemopilema nomurai
}

\author{
Juan Liu, Eun La Kim, Jongki Hong, ${ }^{\dagger}$ Chong-O. Lee, ${ }^{\ddagger}$ Euikyung Kim, ${ }^{\S}$ Won Duk Yoon, ${ }^{\#}$ Famei Li, ${ }^{\mathbb{P}}$ and Jee H. Jung \\ College of Pharmacy, Pusan National University, Busan 609-735, Korea. *E-mail: jhjung@pusan.ac.kr \\ ${ }^{\dagger}$ College of Pharmacy, Kyung Hee University, Seoul 130-701, Korea \\ ${ }^{\star}$ Korea Research Institute of Chemical Technology, Daejon 305-343, Korea \\ ${ }^{\S}$ College of Veterinary Medicine, Gyeongsang National University, Jinju 660-701, Korea \\ ${ }^{\#}$ National Fisheries Research \& Development Institute, Busan 619-705, Korea \\ ${ }^{\mathbb{P}}$ Shenyang Pharmaceutical University, Shenyang 110016, China \\ Received August 21, 2010, Accepted October 1, 2010
}

Key Words: Jellyfish, $\alpha, \omega$-Dicarboxylic acid, Nemopilema nomurai, Cytotoxic activity

Recently, unpredictable blooms of the giant jellyfish Nemopilema nomurai (Scyphozoa: Rhizostomae) were observed in the waters off China, Korea and Japan, which caused significant economic and social damage. ${ }^{1,2}$ Most previous chemical studies on jellyfish focused on their venom. ${ }^{3,4}$ In parallel, several studies have been performed to utilize jellyfish in a productive manner, such as a food stuff or agricultural fertilizers. ${ }^{5}$ This study examined the secondary metabolites of Nemopilema nomurai for subsequent biological evaluations.

A previous study on the anti-inflammatory constituents of this jellyfish isolated a series of lipids including two new alkoxyglycerols. ${ }^{6}$ As part of a continuing search for cytotoxic metabolites from the same jellyfish, a new $\alpha, \omega$-dicarboxylic acid, (2E,4Z)-4-amino-2,3-dimethylheptadeca-2,4-dienedioic acid, was isolated. We describe the structural elucidation and biological evaluation of the compound.

Compound 1 was isolated as a white amorphous solid. HRFABMS revealed a molecular formula of $\mathrm{C}_{19} \mathrm{H}_{33} \mathrm{NO}_{4}$. The precise mass of the $[\mathrm{M}+\mathrm{Na}]^{+}$ion at $\mathrm{m} / z 362.2335$ matched well with the expected formula, $\mathrm{C}_{19} \mathrm{H}_{33} \mathrm{NO}_{4} \mathrm{Na}(\Delta+2.8 \mathrm{mmu})$. The ${ }^{1} \mathrm{H}-$ NMR spectrum suggested the presence of two methyl groups $\left(\delta_{\mathrm{H}} 1.86,2.06\right)$, methylene groups $\left(\delta_{\mathrm{H}} 1.29,1.48,1.58,2.25\right.$, $2.34)$, and an olefinic proton $\left(\delta_{\mathrm{H}} 5.40\right)$. In the COSY spectrum, H-6 $\left(\delta_{\mathrm{H}} 2.34\right)$ showed correlations with $\mathrm{H}-5\left(\delta_{\mathrm{H}} 5.40\right)$ and $\mathrm{H}-7$ $\left(\delta_{\mathrm{H}} 1.48\right)$, and $\mathrm{H}-15\left(\delta_{\mathrm{H}} 1.58\right)$ correlated with $\mathrm{H}-14\left(\delta_{\mathrm{H}} 1.29\right)$ and $\mathrm{H}-16\left(\delta_{\mathrm{H}} 2.25\right)$. The ${ }^{13} \mathrm{C}-\mathrm{NMR}$ spectrum revealed two carboxyl carbon signals $\left(\delta_{\mathrm{C}} 171.6\right.$ and 176.5), indicating this compound to be a dicarboxylic acid. Four ${ }^{13} \mathrm{C}$-NMR signals in the range of 111.3 - 150.2 ppm were indicative of a substituted diene system, which was further supported by the COSY and HMBC correlations (Fig. 2). ${ }^{7}$ The amino group was deduced from molecular formula and the significant downfield shift of C-4 $\left(\delta_{\mathrm{C}}\right.$ 150.2), which indicated that C-4 was connected with an electronegative atom. In the HMBC experiment, two downfield-shifted methyl signals $\mathrm{H}-1^{\prime}\left(\delta_{\mathrm{H}} 1.86\right)$ and $\mathrm{H}-2^{\prime}\left(\delta_{\mathrm{H}} 2.06\right)$ showed correlations with $\mathrm{C}-2\left(\delta_{\mathrm{C}} 123.6\right), \mathrm{C}-3\left(\delta_{\mathrm{C}} 148.0\right)$ and $\mathrm{C}-4\left(\delta_{\mathrm{C}} 150.2\right)$, suggesting a dimethylated diene system. The HMBC correlation between $\mathrm{H}-5\left(\delta_{\mathrm{H}} 5.40\right)$ and $\mathrm{C}-4\left(\delta_{\mathrm{C}} 150.2\right)$ was also observed. A correlation between H-2' $\left(\delta_{\mathrm{H}} 2.06\right)$ and $\mathrm{H}-5\left(\delta_{\mathrm{H}} 5.40\right)$ was observed in the NOESY spectrum, indicating a cis geometry for $\Delta^{4}$ (Fig. 2). The correlation between $\mathrm{H}-1^{\prime}\left(\delta_{\mathrm{H}} 1.86\right)$ and $\mathrm{H}-2^{\prime}\left(\delta_{\mathrm{H}}\right.$ 2.06) was not detectable in the NOESY spectrum, due either

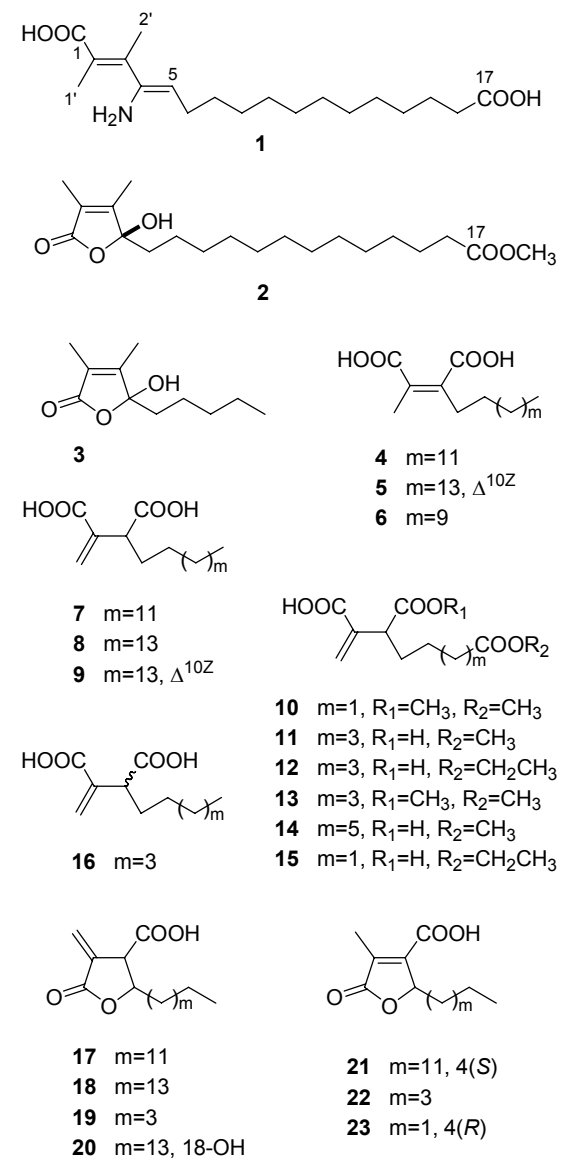

Figure 1. Chemical structures of the compounds.

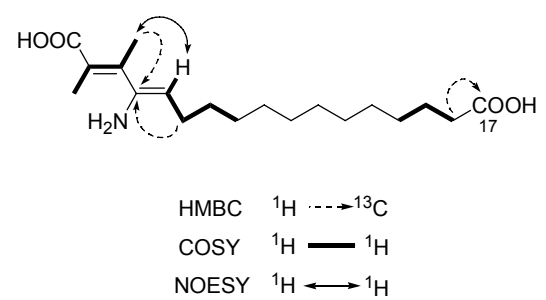

Figure 2. Key COSY, HMBC, and NOESY correlations of compound 1. 
to signal crowding/noise or trans geometry. The geometry of $\Delta^{2}$ can still be defined as $E$ based on the chemical shift of the methyl protons. For similar model compounds, such as 2,3,4,5tetramethyl-hexa-2,4-dienedioic acid ${ }^{8}$ and $\alpha, \beta$-dimethylcinnamamides, the methyl protons $c i s$ to a carbonyl (carboxyl) group were shifted downfield and the chemical shift difference between two allylic protons $\left(\delta_{\mathrm{H}-2^{\prime}}-\delta_{\mathrm{H}-1^{\prime}}\right)$ was larger $(0.42$ and 0.39 ppm, respectively) than the trans counterparts. The trans compounds showed upfield shifted chemical shifts but the chemical shift difference was negligible. Therefore, based on the significant difference in the chemical shifts of the allylic protons (H-1', $\delta_{\mathrm{H}} 1.86 ; \mathrm{H}-2$ ', $\left.\delta_{\mathrm{H}} 2.06\right)$, the $\mathrm{H}-2$ ' methyl group was assigned as cis to the carboxyl group. Accordingly, compound 1 was defined as a new $(2 E, 4 Z)$-4-amino-2,3-dimethylheptadeca-2,4-dienedioic acid, which was given the trivial name nemopilemic acid.

Although dicarboxylic acids do not occur in appreciable amounts as components of animal or vegetable lipids, they are generally important metabolic products of fatty acids because they originate from them by oxidation. ${ }^{9,10}$ However, 2,3-dimethyl carboxylic acids, such as nemopilemic acid, are rare in nature, and only two compounds with analogous carbon skeletons have been reported. Analogous 2,3-dimethylated butenolides $\mathbf{2}$ and $\mathbf{3}$ were reported from the brittle star Ophiomastix mixta and butter fat, respectively (Fig. 1). ${ }^{11,12}$ Biogenetically, nemopilemic acid (1) is believed to be most relevant to the brittle star metabolite (2). Other analogous metabolites including chaetomellic acids A-C (4-6), ${ }^{13,14}$ ceriporic acids A-C (7-9), ${ }^{14,15}$ tensyuic acids A-F (10-15), ${ }^{16}$ hexylitaconic acid (16), ${ }^{17,18}$ pertusaric (18), ${ }^{19}$ methylenolatocin (19), ${ }^{20}$ murolic acid (20), ${ }^{21}$ striatisporolide $\mathrm{A}(\mathbf{2 2}){ }^{22}$ and decumbic acid (23) were isolated from fungi. ${ }^{19}$ Analogous secondary metabolites with a lactonized structure, such as protolichesterinic acid (17) and lichesterinic acid (21), were isolated from lichens. ${ }^{23,24}$ However, amination at C-4 is a noteworthy feature, and was unprecedented in these analogous secondary metabolites. Most of these analogous metabolites with branched and odd-numbered carbon chains were isolated from fungi or lichens, which suggests that hostassociated fungi might be the true producer of nemopilemic acid (1) and 2. Accordingly, a common biosynthetic route may be speculated for this class of compounds. It was reported that compound 3 could be biosynthesized from angelic acid and caproic acid. ${ }^{25}$ On the other hand, the biosynthesis of hexylitaconic acid (16) was proposed to be the condensation of oxaloacetate with $\alpha$-methylene group of acyl-CoA. ${ }^{26}$ In the former biosynthetic route, the $\mathrm{C}_{5}$ carbon skeleton including two methyl branches was derived from angelic acid. However, in latter biosynthetic route, the $\mathrm{C}_{3}$ carbon skeleton, including one methylene branch, was derived from oxaloacetate. A further intensive study

Table 1. Cytotoxicity of compound $\mathbf{1}^{a}$

\begin{tabular}{cccccc}
\hline Compound & A549 & SK-OV-3 & SK-MEL-2 & XF498 & HCT15 \\
\hline $\mathbf{1}$ & 19.56 & $>30.0$ & 24.31 & 27.07 & 24.22 \\
Doxorubicin & 0.01 & 0.04 & 0.01 & 0.04 & 0.01
\end{tabular}

${ }^{a}$ Data is expressed in $\mathrm{ED}_{50}$ values $(\mu \mathrm{g} / \mathrm{mL})$. A549, human lung cancer; SK-OV-3, human ovarian cancer; SK-MEL-2, human skin cancer; XF498, human CNS cancer; HCT15, human colon cancer. will be needed to resolve the contradictory biosynthesis of this class of compounds.

The analogues of chaetomellic acid (4-6) are viable targets for the development of antitumor drugs due to their strong inhibitory effects on RAS farnesyl-protein transferase (FPTase). ${ }^{15}$ Therefore, compound $\mathbf{1}$ was subjected to a cytotoxicity evaluation against a panel of five human solid tumor cell lines (A549, SK-OV-3, SK-MEL-2, XF498, and HCT15) but only marginal cytotoxicity was observed (Table 1).

\section{Experimental Section}

General experimental procedures. The ${ }^{1} \mathrm{H}$ - and ${ }^{13} \mathrm{C}-\mathrm{NMR}$ spectra were recorded on UNITY 400 and Varian INOVA 500 instruments. The chemical shifts were reported with reference to the respective residual solvent or deuterated solvent peaks $\left(\delta_{\mathrm{H}} 3.30\right.$ and $\delta_{\mathrm{C}} 49.0$ for $\mathrm{CD}_{3} \mathrm{OD}$ ). The FABMS data were obtained on a JEOL JMS SX-102A. HRFABMS was performed on a JEOL JMS SX-101A. HPLC was performed on an YMC ODS-H80 column $(250 \times 10 \mathrm{~mm}$ i.d., $4 \mu \mathrm{m}, 80 \AA)$ with a Shodex RI-71 detector.

Animal material. The jellyfish was collected off the southern coast of Korea in June 2007. The specimen was identified by Dr. W. D. Yoon. A voucher specimen of the jellyfish was deposited in the National Fisheries Research \& Development Institute, Busan, Korea.

Extraction and isolation. The frozen jellyfish $(146.2 \mathrm{~kg}$ ) was extracted exhaustively with EtOAc at room temperature. Guided by its lethality to brine shrimp larvae, the EtOAc extract $\left(\mathrm{LD}_{50}\right.$ 269.0 - $325.7 \mu \mathrm{g} / \mathrm{mL})(10.7 \mathrm{~g})$ was partitioned further between aqueous $\mathrm{MeOH}\left(\mathrm{LD}_{50} 268.2 \mu \mathrm{g} / \mathrm{mL}\right)(7.6 \mathrm{~g})$ and $n$-hexane $\left(\mathrm{LD}_{50}>1000 \mu \mathrm{g} / \mathrm{mL}\right)(2.8 \mathrm{~g})$. The aqueous $\mathrm{MeOH}$ fraction was subjected to stepped gradient MPLC (ODS-A, $120 \AA$, S-30/50 mesh) eluting with 60 to $100 \% \mathrm{MeOH}$ to afford 12 fractions. Fraction 3 (186.2 mg) was separated by reversed-phase HPLC (YMC ODS-H80, $250 \times 10 \mathrm{~mm}, 4 \mu \mathrm{m}, 80 \AA$ ) eluting with $80 \%$ $\mathrm{MeOH}$ to afford 8 subfractions. Subfraction $4(5.3 \mathrm{mg})$ was purified by reversed-phase HPLC (YMC ODS-H80, $250 \times 10$ $\mathrm{mm}, 4 \mu \mathrm{m}, 80 \AA$ ) eluting with $90 \% \mathrm{MeOH}$ to yield compound 1 (1.1 mg).

Nemopilemic acid (1): White amorphous solid; ${ }^{1} \mathrm{H}-\mathrm{NMR}$ $\left(\mathrm{CD}_{3} \mathrm{OD}, 500 \mathrm{MHz}\right) \delta 5.40(1 \mathrm{H}, \mathrm{t}, J=7.5 \mathrm{~Hz}, \mathrm{H}-5), 2.34(2 \mathrm{H}$, td, $J=7.5,7.5 \mathrm{~Hz}, \mathrm{H}-6), 2.25$ (2H, t, $J=7.0 \mathrm{~Hz}, \mathrm{H}-16), 2.06$ $\left(3 \mathrm{H}, \mathrm{s}, \mathrm{H}-2^{\prime}\right), 1.86\left(3 \mathrm{H}, \mathrm{s}, \mathrm{H}-1^{\prime}\right), 1.58(2 \mathrm{H}, \mathrm{m}, \mathrm{H}-15), 1.48(2 \mathrm{H}$, m, H-7), 1.29 (14H, bs, H-8 14); ${ }^{13} \mathrm{C}-\mathrm{NMR}\left(\mathrm{CD}_{3} \mathrm{OD}, 400 \mathrm{MHz}\right)$ $\delta 176.5$ (C-17), $171.6(\mathrm{C}-1), 150.2$ (C-4), 148.0 (C-3), 123.6 (C-2), 111.3 (C-5), 33.7 (C-16), 29.0-29.6 (C-7 14), 25.7 (C-6), 24.9 (C-15), 8.5 (C-2'), 7.2 (C-1'); LRFABMS m/z 338 [M - H]', HRFABMS $m / z 362.2335[\mathrm{M}+\mathrm{Na}]^{+}$(calcd for $\mathrm{C}_{19} \mathrm{H}_{33} \mathrm{NO}_{4} \mathrm{Na}$, 362.2307).

Evaluation of cytotoxicity. Rapidly growing cells were harvested, counted and inoculated at the appropriate concentrations $\left[(1-2) \times 10^{4}\right.$ cells/well $]$ onto 96 -well microtiter plates. After incubation for $24 \mathrm{~h}$, the compounds dissolved in the culture medium (RPMI 1640, Gibco; 10\% FBS, Gibco) were applied to the culture wells in triplicate followed by incubation at $37{ }^{\circ} \mathrm{C}$ in for $48 \mathrm{~h}$ an atmosphere containing $5 \% \mathrm{CO}_{2}$. The culture was fixed with cold trichloroacetic acid and stained with $0.4 \% \mathrm{SRB}$ 
(sulforhodamine B, Sigma) dissolved in 1\% acetic acid. After dissolving the bound dye with $10 \mathrm{mM}$ unbuffered Tris base using a gyrotatory shaker, the absorbance at $520 \mathrm{~nm}$ was measured using a microplate reader (Dynatech Model MR 700). The fifty percent inhibitory concentration $\left(\mathrm{ED}_{50}\right)$ was defined as the concentration that reduced the absorbance by $50 \%$ compared to the control level in the untreated wells.

Acknowledgments. This study was supported by a grant from the Ministry of Land, Transport, and Maritime Affairs, Korea.

\section{References}

1. Yasuda, T. Nippon Suisan Gakkaishi. 2004, 70, 380.

2. Kawahara, M.; Uye, S. I.; Ohtsu, K.; Iizumi, H. Mar. Ecol. Prog. Ser. 2006, 307, 161.

3. Kawahara, M.; Uye, S. I.; Burnett, J.; Mianzan, H. Toxicon. 2006, $48,713$.

4. Kim, E.; Lee, S.; Kim, J. S.; Yoon, W. D.; Lim, D.; Hart, A. J.; Hodgson, W. C. Toxicology Lett. 2006, 167, 205.

5. Fukushi, K.; Arita, T.; Minami, S.; Kitakata, M.; Tsujimoto, J.; Yamashita, Y. Nippon Kaisui Gakkaishi. 2006, 60, 173.

6. Liu, J.; Li, F. M.; Hong, J.; Kim, E. L.; Yoo, E. S.; Kim, E.; Yoon, W. D.; Jung, J. H. Nat. Prod. Sci. 2009, 15, 71.

7. Balsamo, A.; Barili, P. L.; Crotti, P.; Macchia, B.; Macchia, F.; Pecchia, A. J. Med. Chem. 1975, 18, 842.

8. Adam, W. Chem. Ber. 1964, 97, 1811.

9. Verkade, P. E.; Lee, J. V. D. Biochem. J. 1934, 28, 31.

10. Wada, F.; Usami, M. Biochim. Biophys. Acta 1977, 487, 361.
11. Lee, J.; Wang, W.; Hong, J.; Lee, C.-O.; Shin, S.; Im, K. S.; Jung, J. H. Chem. Pharm. Bull. 2007, 55, 459.

12. Boldingh, J.; Taylor, R. J. Nature (London) 1962, 194, 903.

13. Singh, S. B.; Zink, D. L.; Liesch, J. M.; Goetz, M. A.; Jenkins, R. G. Tetrahedron 1993, 49, 5917 .

14. Amirta, R.; Fujimori, K.; Shirai, N.; Honda, Y.; Watanabe, T. Chem. Phys. Lipids. 2003, 126, 121.

15. Enoki, M.; Honda, Y.; Kuwahara, M.; Watanabe, T. Chem. Lett. 2000, 29, 54.

16. Hasegawa, Y.; Fukuda, T.; Hagimori, K.; Tomoda, H.; Omura, S. Chem, Pharm. Bull. 2007, 55, 1338.

17. Nanjo, K.; Kora, S.; Suzuki, A.; Isogai, A. Jpn. Kokai Tokkyo Koho JP62132804. 1985.

18. Tsukamoto, S.; Yoshida, T.; Hosono, H.; Ohta, T.; Yokosawa, H. Bioorg. Med. Chem. Lett. 2006, 16, 69.

19. He, G.; Matsuura, H.; Yoshihara, T. Phytochemistry 2004, 65, 2803

20. Park, B. K.; Nakagawa, M.; Hirota, A. J. Antibiot. 1988, 6, 751.

21. Huneck, S.; Schreiber, K.; Hoefle, G.; Snatzke, G. J. Hattori Bot. Lab. 1979, 45, 1.

22. Stewart, M.; Capon, R. J.; Lacey, E.; Tennant, S.; Gill, J. H. J. Nat. Prod. 2005, 68, 581.

23. Ingolfsdottir, K.; Hjalmarsdottir, M. A.; Sigurdsson, A.; Gudjonsdottir, G. A.; Brynjolfsdottir, A.; Steingrimsson, O. Antimicrob. Agents Chemother. 1997, 41, 215.

24. Van Tamelen, E. E.; Osborne, C. E., Jr.; Bach, S. R. J. Am. Chem. Soc. 1955, 77, 4625 .

25. Shunsuke, I.; Li, C.; Ayako, N.; Yosuke, N.; Kei, S.; Toshifumi, H. Tennen Yuki Kagobutsu Toronkai Koen Yoshishu 1996, 38, 1.

26. Bonnarme, P.; Gillt, B.; Sepulchre, A. M.; Role, C.; Beloeil, J. C.; Ducrocq, C. J. Bacteriology 1995, 177, 3573. 